\title{
IMPACTS OF DRINKING WATER INFRASTRUCTURES RISKS
}

\author{
Jan Prochazka, Dana Prochazkova, Miroslav Rusko, Milan Majernik, \\ Vojtech Kollar, Jan Ilko \& Stefan Majernik
}
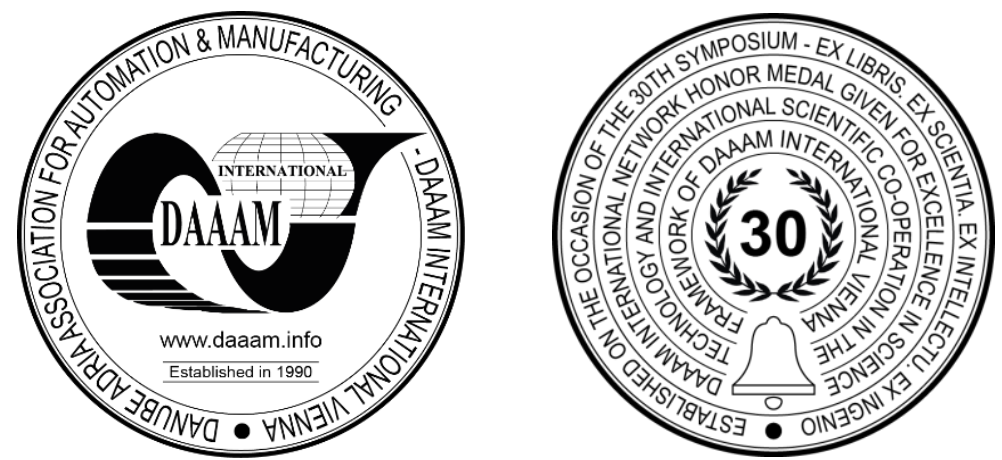

This Publication has to be referred as: Prochazka, J[an]; Prochazkova, D[ana]; Rusko, M[iroslav]; Majernik, M[ilan]; Kollar, V[ojtech] \& Ilko, J[an] (2020). Impacts of Drinking Water Infrastructures Risks, Proceedings of the 31st DAAAM International Symposium, pp.0356-0365, B. Katalinic (Ed.), Published by DAAAM International, ISBN 978-3-902734-29-7, ISSN 1726-9679, Vienna, Austria

DOI: $10.2507 / 31$ st.daaam.proceedings.050

\begin{abstract}
The drinking water supply network is important part of critical infrastructure of each country. Therefore, protection of drinking water supply network is under special interest. The drinking water supply network has three variants of network topology: a) branch, b) loop and c) combined. The paper describes the impacts of drinking water supply in Central Bohemia region if the failure is caused by two different origins, i.e. by the disruption of distribution network and contamination with toxic substance in one of drinking water source. The Ishikawa diagram shows sources of the drinking water supply failures. By special form of "What, If" method, they are shown the impacts of disruption of distribution network for drinking water supply and the impacts of contamination of source by toxic substance.
\end{abstract}

Keywords: Drinking water supply; Failure of supply; Distribution network disruption; Contamination.

\section{Introduction}

The life and health of people depend on the public assets, which include the critical infrastructure [1]. A network of drinking water supply is one of basic infrastructures, which belongs to the critical infrastructure in all developed countries [2]. The term of critical infrastructure is introduced in the Czech legislation by the Law No. 240/2000 Coll., and described by the Government Ordinance No. 432/2010 Sb. Present paper deals with technical look, when we consider the critical infrastructure as a set of elements, links and flows, where the elements may be the liner and point structures, processes or management [2]. Set of all parts together and their interdependencies, then provides a certain service, necessary for the operation or survival of human system [1], [2], [3]. This problem has to be solved also for communities, which introduce the concept of "smart cities".

We have to especially recognize the close interconnectedness of individual systems in case of risk management [8], and safety management of critical infrastructure and individual infrastructures [3], which make up the critical infrastructure and which we describe by models "systems of systems". The put out of operation of one system, one infrastructure then sooner or later has a negative effect on the functioning the other infrastructures that form critical infrastructure [2], [3]. The criticality of certain infrastructures is then so high that their put out of operation means fast disruption and put out of operation of other services, namely even the most critical. At infrastructures with very high criticality it is required especially quick response in a sufficient scale [3]. 
From these reasons, the failures of certain infrastructures are included in the category of critical disasters, for which it is necessary to prepare the response on the level of crisis management [1]. As the article suggests, the supply of drinking water network is one of such infrastructures. We will deal with the causes of drinking water supply failure, the possible impacts and the conditions for cope with the emergency situation.

\section{Critical infrastructure and its components}

Critical infrastructure includes a series of infrastructures; and the supply of drinking water is one of elementary part of critical infrastructure [2]. We can explore properties of selected infrastructure from the perspective of external links on other protected interests of human system and on other infrastructures. For each infrastructure it is important internal topology of networks and processes [17].

The most of studies, which deal with critical infrastructure failure, describe blackout connected with electricity infrastructure. The comparison of drinking water supply failure and electricity infrastructures failure is shown in Fig. 1. The failure of both mentioned infrastructures leads to the serious losses and damages to human health within a few days [18]. In Fig. 1 it is divided infrastructures on hard elements (hardware), soft elements (software) and human resources.

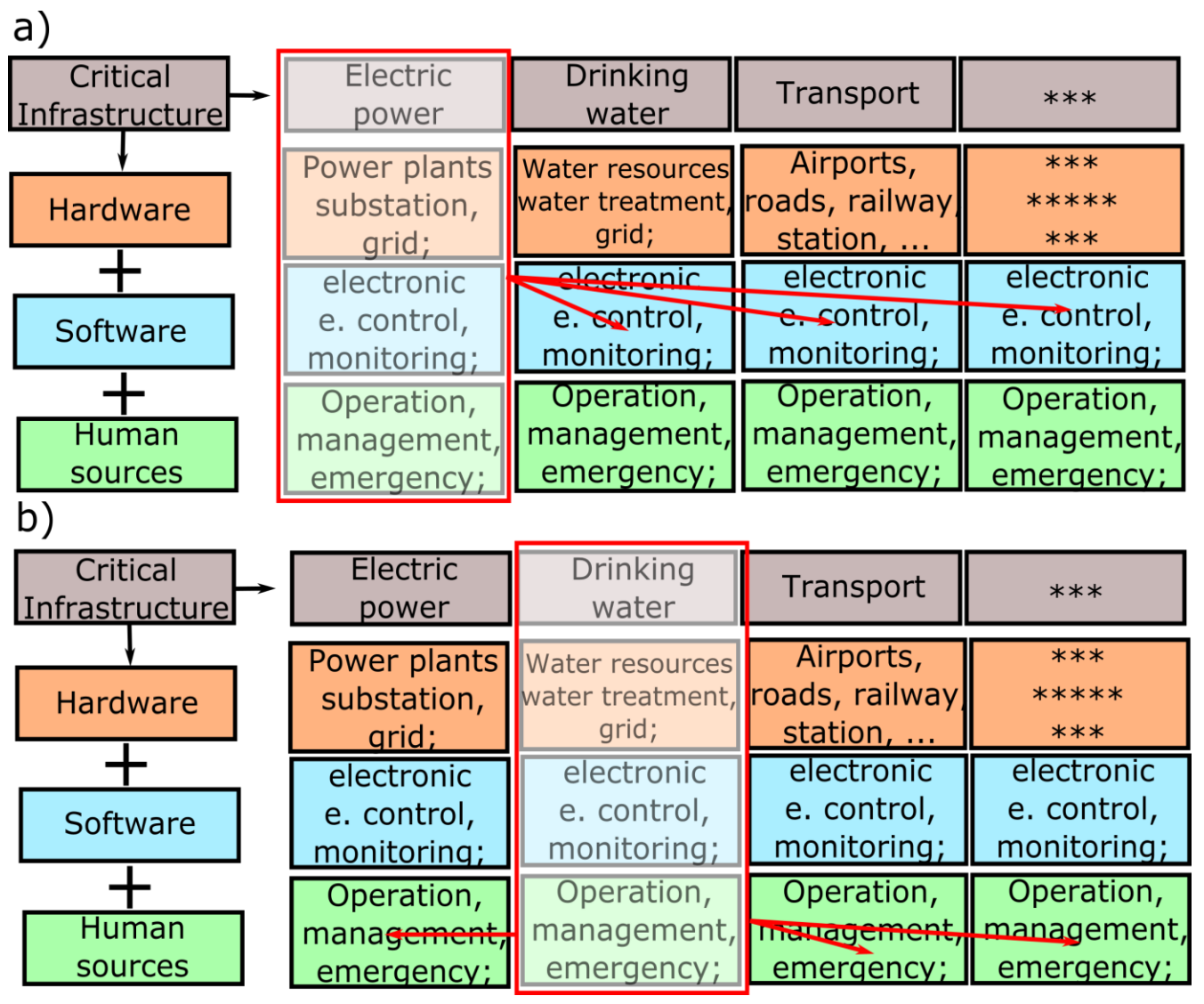

Fig. 1. Diagram of impacts of critical infrastructures failures on the elements of other critical infrastructures, a) electricity supply failures), b) drinking water supply failure

The hardware is formed by physical construction, liner and point, necessary for the operation of given service provided from the source, through the transport up to the distribution. The hardware is mainly threatened by natural disasters, technological accidents or attacks. The hardware could potentially themselves provide the service, but not in the required form and functional range. Services need software elements for working in the required range and quality. Software consists of processes, controls and monitoring. The processes are carried out either cyber or human support staff. The disruption of software can be caused by a failure of other infrastructure (electric, cyber) or by a human error (routine in the execution of process, wrong management processes). Even in the case that we would be technologically able to build an autonomous infrastructure just from hardware and software (cyber elements), the infrastructure could not without the human factor meet the requirements, which are imposed on it in the long term. The last part of the infrastructure, namely the human resources, has an influence at defining the structure of network (both, the physical and the procedural). Human resources are necessary for response to changes in progress of human system, new demands and new threats. Last but not least many routine processes we are not able to adequately automate. Human resources are vulnerable to all the disasters [8]. 
When we return Fig. 1, we see a comparison of impacts of failure of electrical power supply and failure of drinking water supply. We can identify the impacts on the protected interests of all types in both cases, namely on all types of infrastructures. In the case of failure of electricity networks, it goes on put out of operation of software elements of all the other infrastructures, which will be out of operation immediately or within a few hours. The failure of drinking water supply has a slightly slower impact; however, it directly affects the people and it put out of operation the other infrastructure through human resources within a few days.

\section{Topology of drinking water supply network}

While the character of software elements and human resources can be completely different for different companies and different regions, the hardware part of infrastructure is similar everywhere in basic aspects. It has the resources, transport elements and distribution elements. Parameters, that define the properties of hardware of infrastructure of drinking water supply, are a lot. We will focus only on the main two parameters. The first parameter is located in domain of drinking water sources, the other in domain of transport - i.e. the network topology.

The basic sections of drinking water sources are on surface sources and underground sources, which can be further divided according to parameters like area, depth, volume, quality and so on. Each of two types of resources, ground and surface, has its advantages and disadvantages. The economic benefits of underground resources were recently preferred. We can point at several differences from the perspective of risk analysis. Groundwater need less treatment then surface water. Groundwater sources have less probability of contamination, although due to very low protection occasionally smaller sources contamination occurs for example due to road traffic accidents [9], [10]. Cleaning of pollute groundwater resources is currently not technologically possible. The main advantage of surface water sources is their renewability, that is associated purely with precipitation, and it is not dependent on the ratio of seeped and flow away water.

Transmission networks are composed mainly of pipeline in addition to the elements that ensure the water pressure in system. The network topology is fundamental feature of distribution network, where we know the three variants of topology, Fig. 2 [11]. The cheapest option is to construct a branched network, where ever places of water distribution system are brought only by one pipeline [11], [12]. At the branched network it is the high probability of total collapse of network at simple faults. A loop network is an opposite of the branched network, and it supplies the water to all points of loop network from two directions. The costs for constructing the circuit network are high, but the disruption only its part requires the coincidence of many circumstances and the disruption of entire network can only be caused in reality by intent. The best solution for practical use seems to be the combined network of loops and branches, which brings advantages of both networks at proper design and management; i.e., reasonable costs and high resistance at the level of main part of network. The ratio of combination of loops and branches depends on the objectives of network. The objective of drinking water distribution in the Czech Republic is the combined network. The risk of major failure is shifted to the domain of water resources in combined supply system. However, existed networks in the Czech Republic are mainly branched networks and change depends on finance.

a)

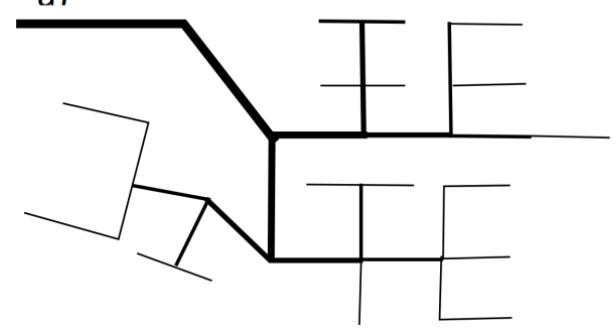

b)

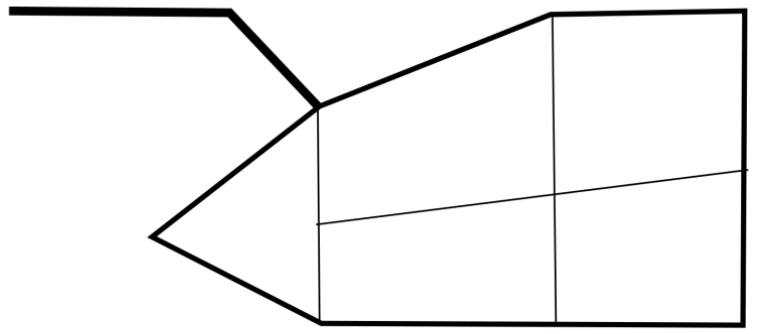

c)

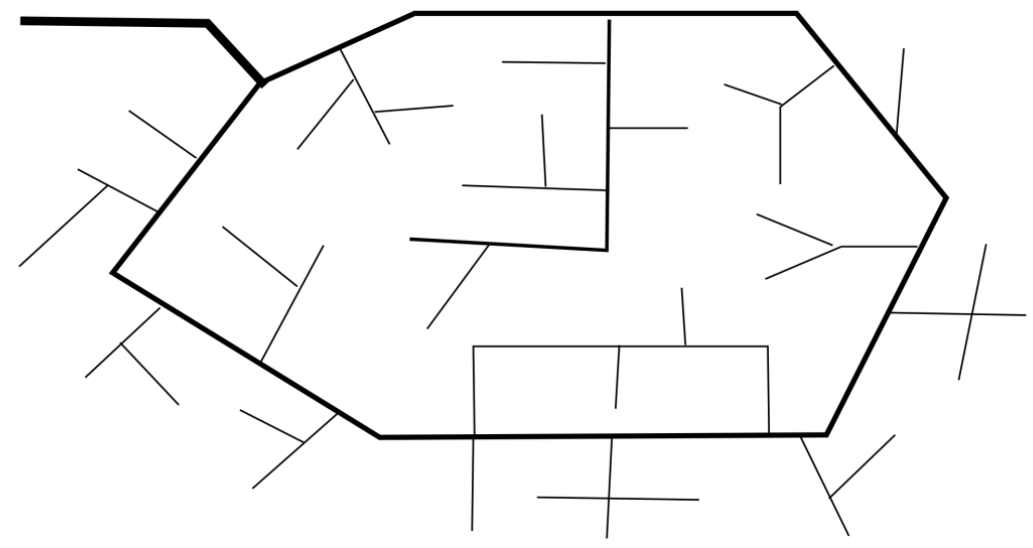

Fig. 2. Models of three variants of drinking water supply network topology: a) branch, b) loop and c) combined 


\section{Causes of drinking water supply failure}

Vulnerability of infrastructures to damage is quite high. Many causes and processes can lead to the disruption of network [2], [3]. To some of causes, for example, to occurrence of natural disasters it is not possible to defeat. The main problem of many countries there are causes which are entirely in the hands of public administration and owners of water supply network, namely construction, maintenance and monitoring of pipelines. Causes of water supply failures can be separated by several ways; i.e. according to: elements that are disturbed; the size of impacts; region of origin of failure; characteristics of failure. The causes corresponding to last mentioned reasons are shown in Fig. 3, that is constructed on data from [11] with the help of Ishikawa diagram [8]. The backbone of fish bone in Fig. 3 is the drinking water supply network and the causes of water supply failures are demonstrated in six different branches.

The wrong construction is a group of causes, which have origin in designing or in building phases of pipelines. Incompetent designer or attempt for the lowest costs on building and construction can lead to origin of many frequent breakdowns, high repair costs, or to the low efficiency of required services.

Surrounding subterranean environs affects permanently on network by its spreading and shrinking in dependence on various geomorphological conditions. The probability of disruption is then given by structure, material aging and the quality of maintenance of pipelines. Other problems there are natural disaster, which may reach different sizes and cause varied damages on infrastructure. Pipelines are resistant to smaller disasters, however, several disasters damage seriously infrastructure, and therefore, it is necessary to have prepared in the frame of crisis plan the different variants of alternative sufficient water supply [1], [13]. Influences of environment cannot be prevented in any way.

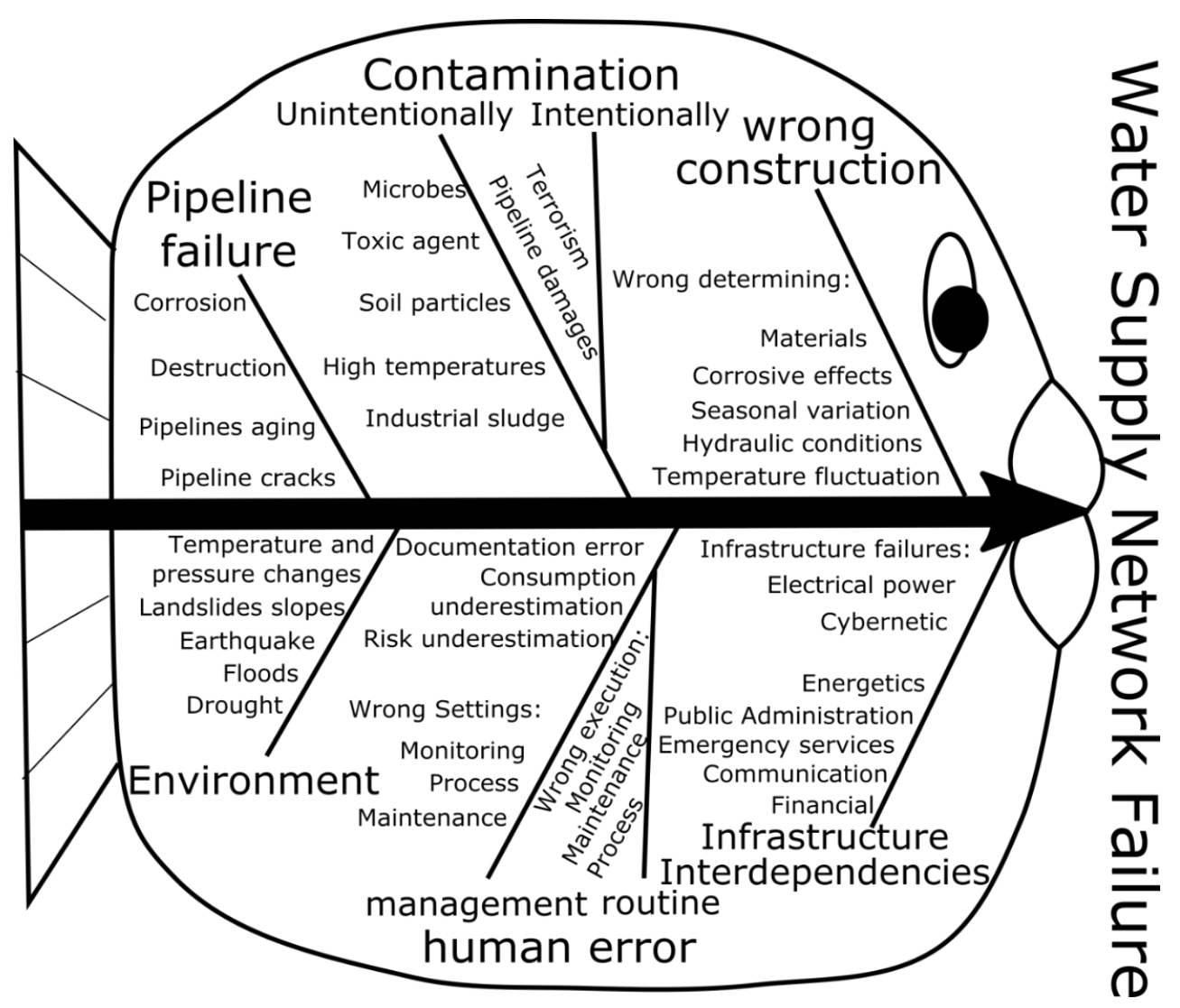

Fig. 3. Ishikawa diagram for the drinking water supply failure

Infrastructures interdependencies are discussed in paragraph 2. The failure of certain infrastructures may cause a critical situation, and similarly as at natural disasters it requires the sufficient high-quality crisis plan. Critical infrastructure protection is a necessary part of modern crisis management.

Human error has several dimensions. It includes errors at designing or at building the structure [8], which have their own branch in Fig. 3. In mentioned figure we can see human errors during the operation of network. Human errors can arise during the management, e.g. bad estimate of water consumption. The increase of drinking water demands is necessary to foresee, because building the new water resources is time consuming. Human errors connected with routine operation are caused by violation of technical norms, standards and determined procedures. Technical problem is caused by routine human error, if ordered procedure is not kept. If the procedures have been kept, then it is a mistake of management at setting the operation regime. In the Czech Republic problems are primarily connected with organizational accidents [1], [3], i.e. the persons in management do not ensure his / her responsibility. 
The pipeline failure is the most common cause of drinking water supplies disruption. The main causes are incorrect structure, age and maintenance quality. If someone of these three factors, is failing, the pipeline cracks and damages occur as consequence of common phenomena.

Contamination can be divided into intentional and unintentional. Water resources are one of the possible targets of terrorist attacks, which can cause great damages. In the case of highly toxic substances it may also come to the pollution of entire network through small source of pollution. It is, therefore, important to protect the perimeter of resources and above all, to monitor the water quality supplied to the network [14]. Relatively common in recent years it has been the unintentional contamination. Its causes are drought and high temperatures, poor documentation, an accident during the transport of dangerous goods, storage of hazardous substances and harmful things near the water sources, which happened in recent years in the Czech Republic [10]. Contamination of water source may cause a critical situation also in the case of durable drinking water supply infrastructure.

\section{Data and methods used in the research of drinking water supply failure}

For monitoring the impact of drinking water supply failure, it was selected the part of Central Bohemia. We used data on the layout of resources and on the network topology [15], [16]. From safety reasons we only show the rough model of distribution network, Figure 4, which we created from detail real data. The mentioned figure shows that we consider combined network with two water sources that has in internal part the branched networks. It means that there are all problems of network types, the combined and the branched, plus even more problems. Our network includes two sources; the primary source $\boldsymbol{A}$ is a source of underground water, $80 \%$ all water. Source $\boldsymbol{B}$ is a surface water source and it provides $15 \%$ all water. The rest is covered with smaller resources. The predominance of underground resource corresponds to the situation, when the underground water is cheaper than surface water. New knowledge and experiences on hydrological changes and recent droughts supports returning to higher portion of surface water [15], [16].

The impacts of a critical failure of drinking water supply are locally specific and depend on the scenario, which led to the failure. At all critical failures, citizens have lack of drinking water. At research of drinking water supply critical failure impacts we used the "What if" analysis [8] modified for the needs of security problems in an integral and systemic conception of reality. We followed two possible cases, namely the large disruption of distribution network and the large contamination of source by highly dangerous substance.

Any contamination has several concentration levels, from which there are derived human health damages, or losses of human lives [1]. In the case of highly toxic substances it may get to human life threat even at the dilution in the huge quantities of water, and therefore, to the danger of all consumers of water from contaminated infrastructure. It is not essential, where the contamination occurred, if in main source, secondary sources, the water tank, the piping. It is also necessary to consider that after the put out of operation of infrastructure it can be very problematic the decontamination of whole network. The network may be out of function in the case of insufficient response for several days, which is from the perspective of physiological needs of human too long [1].

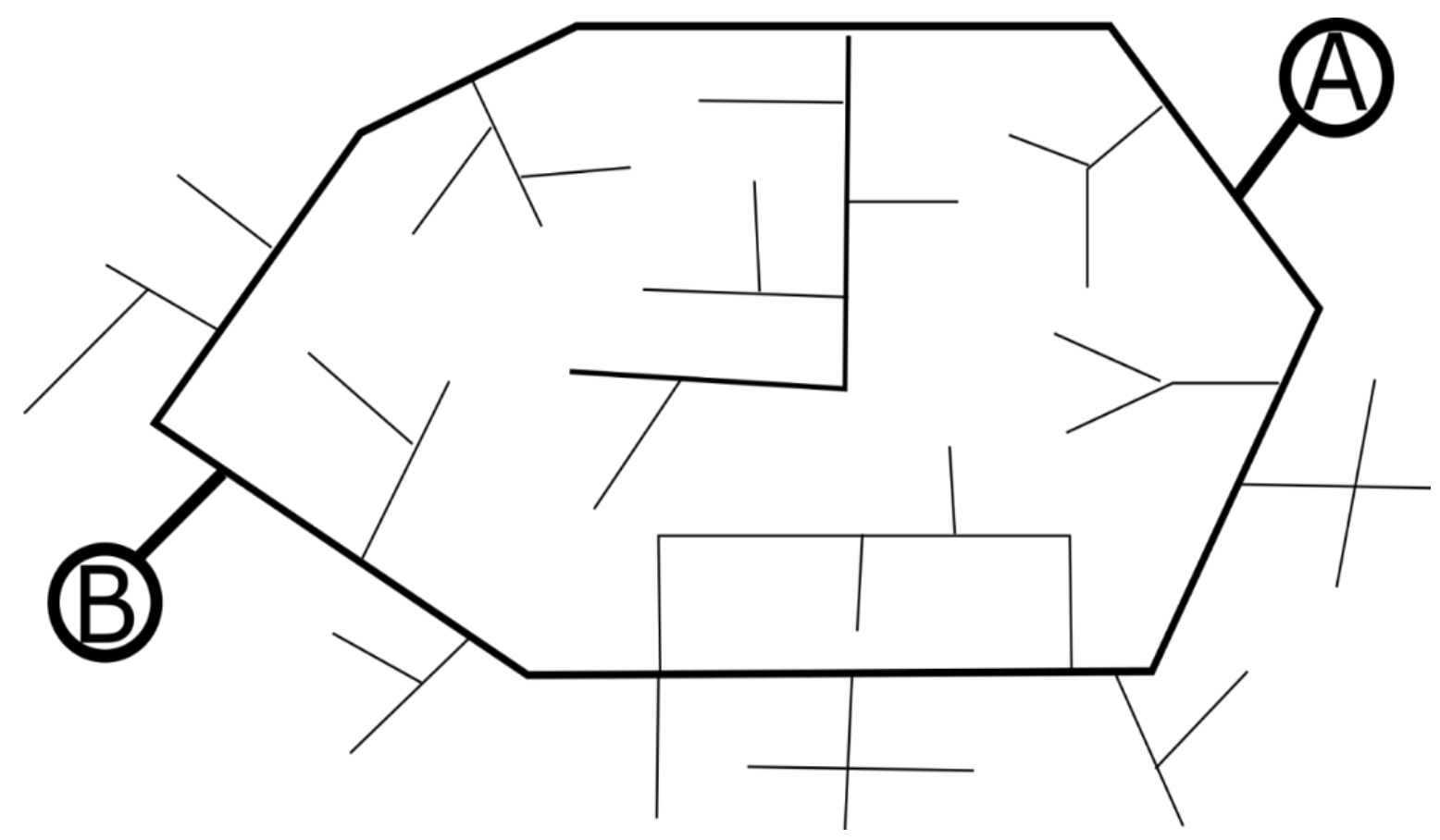

Fig. 4. Combined network of drinking water supply with two main water resources, $\mathrm{A}-$ underground $80 \%$ of all water and $\mathrm{B}$-surface $15 \%$ of all water 


\section{Impacts of the selected scenarios of drinking water supply failure}

We selected two scenarios, disruption of distribution network and contamination with toxic substance. Disruption of distribution network is presumed on connection of main source. Contamination describe situation, when substance with high toxicity get to water. Contamination does not be necessary in place of main sources.

\subsection{Disruption of distribution network}

Large water sources are always a critical part of the drinking water supply infrastructure. Criticality of the main pipelines is very high in the case of the branched network [11], but it is not so high for the combined network. Although our supposed network in Fig. 4 is combined, we have only one line between the main source A (80\%) and the rest of the network. Criticality of source connection is the same as criticality of source itself, if connections are not more than one. We assumed the disruption of such connections in the first scenario. It is necessary to note that pressure of water needs not to fall below a certain amount for the proper functioning of network. At outage of $80 \%$ on input the pressure drops very quickly, water will not be available in all networks without the introduction of tough regulation on output, though not all sources would be knocked out [15]. The impacts of disruption of distribution network are in Table 1.

\begin{tabular}{|c|c|}
\hline Public assets & Impacts \\
\hline $\begin{array}{l}\text { Lives and health of } \\
\text { humans }\end{array}$ & $\begin{array}{l}0 \mathrm{~h} \text { : } \\
12 \mathrm{~h} \text { : light dehydration persons dependent on the supply of drinking water from the water supply } \\
\text { network (those who do not have access to the water packed), leading to damage of health and } \\
\text { lives of people with a higher vulnerability on lack of drinking water, i.e., particularly persons } \\
\text { for long time ill, patients in hospitals, older persons and children. } \\
24 \mathrm{~h} \text { : dehydration of all persons dependent on supplies of drinking water from the water supply } \\
\text { network (those who do not have access to the water packed). The lack of water affects headache } \\
\text { and reducing the blood pressure. } \\
3 \text { days: increasing the dehydration. Persons with increased sensitivity to lack of fluid can died. } \\
\text { Most of population suffers from dehydration symptoms, such as headache, pressure decrease, } \\
\text { increase in heart rate and other physiological manifestations. Dehydration is already affecting } \\
\text { the people who were frontloaded by bottled water. At all residents of affected area, it is starting } \\
\text { to show the stress from emergency situation and it is also getting worse mental state. The } \\
\text { deteriorating level of hygiene. } \\
7 \text { days: severe dehydration causing death of inhabitants. }\end{array}$ \\
\hline Human security & $\begin{array}{l}0 \mathrm{~h}: 12 \mathrm{~h} \text { : } \\
24 \mathrm{~h} \text { : the increase of tension in the society. } \\
3 \text { days: as a result of the decline in the quality of emergency services it goes to increase of } \\
\text { possibility of origin of other disasters. } \\
7 \text { days: the loss of all internal security features, and it leads to big increase of possibility of } \\
\text { further disasters origin. }\end{array}$ \\
\hline Property & $\begin{array}{l}0 \mathrm{~h}: \\
12 \mathrm{~h} \text { : property damage by fire. } \\
24 \mathrm{~h} \text { : disrupting the functionality of machines and equipment that are dependent on the supply } \\
\text { of water. Damage of property caused by fire. } \\
3 \text { days: the origin of unrest within the society leading to the looting and destruction of property. } \\
\text { Property damage caused by fire, the likelihood of which increases due to the degradation of } \\
\text { society. } \\
7 \text { days: property damage by huge long-term fires. }\end{array}$ \\
\hline $\begin{array}{l}\text { Public good } \\
\text { (welfare) }\end{array}$ & $\begin{array}{l}0 \mathrm{~h} \text { : } \\
12 \mathrm{~h} \text { : interruption of work activities in the private and the public sphere. A forced holiday due } \\
\text { to failure of compliance with the requirements in the labour code. The unavailability of } \\
\text { restaurants and cultural facilities. } \\
24 \mathrm{~h} \text { : } \\
3 \text { days: the deterioration of situation in human society. Negative effect on the perception of } \\
\text { territory in the future. } \\
7 \text { days: as a result of disintegration of society due to mental and physical health of population } \\
\text { the term public good loses its meaning. }\end{array}$ \\
\hline Environment & $\begin{array}{l}0 \mathrm{~h}: 12 \mathrm{~h}: 24 \mathrm{~h} \text { : } \\
3 \text { days: due to the affection of civic discordances and disruption of emergency services it } \\
\text { increases the possibility of origin of further disasters affecting the environment, e.g. fires, waste } \\
\text { water. } \\
7 \text { days: the increase of impacts of unresolved calamities on environment. }\end{array}$ \\
\hline
\end{tabular}




\begin{tabular}{|c|c|}
\hline $\begin{array}{l}\text { Water supply } \\
\text { system }\end{array}$ & $\begin{array}{l}0 \mathrm{~h} \text { : a significant worsening in the functioning of drinking water supply infrastructure. } \\
12 \mathrm{~h} \text { : the depletion of storage network systems, water towers. } \\
24 \mathrm{~h} \text { : } \\
3 \text { days: Out of function of all systems of drinking water supply infrastructure. } \\
7 \text { days: degradation of mechanical parts of system of drinking water supply network (the } \\
\text { elements of system are not in conditions on which they have been designed). }\end{array}$ \\
\hline $\begin{array}{l}\text { Emergency } \\
\text { services (police, } \\
\text { fire-fighters, } \\
\text { paramedics) }\end{array}$ & $\begin{array}{l}0 \mathrm{~h} \text { : a sudden drop in pressure in the water line, the failure of some sources of water designed } \\
\text { for extinguishing fires. } \\
12 \mathrm{~h} \text { : the worsening the conditions of patients in hospital devices. The worsening the availability } \\
\text { of medical rescue services due to the transfer of patients outside of the affected area. } \\
24 \mathrm{~h} \text { : } \\
3 \text { days: the decline of physical possibility of emergency services workers caused by dehydration. } \\
\text { The gradual attacks of staff of emergency services in the wake of deteriorating situation in the } \\
\text { human society. } \\
7 \text { days: malfunction of internal components of infrastructure. }\end{array}$ \\
\hline Transpol & $\begin{array}{l}0 \mathrm{~h}: 12 \mathrm{~h} \text { : } \\
24 \mathrm{~h} \text { : possible formation of traffic jams as a result of migration of population from the affected } \\
\text { area. } \\
3 \text { days ago: origin of traffic jams on road network as a result of evacuation of population. The } \\
\text { failure of internal elements of territorial railway network. Disruption of pipeline elements of } \\
\text { transport infrastructure as the result of social unrest. } \\
7 \text { days: malfunction of all elements of transport associated with human activities. Damage to } \\
\text { the mechanical elements of transport infrastructure as the result of secondary disasters, e.g., } \\
\text { traffic accidents, fires, riots, etc. }\end{array}$ \\
\hline $\begin{array}{l}\text { Other basic } \\
\text { services and } \\
\text { critical } \\
\text { infrastructures } \\
\text { (informational, } \\
\text { financial, energy, } \\
\text { social, State) }\end{array}$ & $\begin{array}{l}0 \mathrm{~h}: \\
12 \mathrm{~h} \text { : non-availability of basic services, e.g. educational institutions, governmental (public } \\
\text { administration) and financial services. } \\
24 \text { h: loss of packaged liquids in stores and distribution centres. } \\
3 \text { days: malfunction of internal elements of the basic infrastructures and critical services. } \\
7 \text { days: }\end{array}$ \\
\hline
\end{tabular}

Table 1.The impacts of disruption of distribution network for drinking water supply; 0-time of disruption, $12 \mathrm{~h}-12$ hours after disruption, $24 \mathrm{~h}-24$ hours after disruption, 3 days and 7 days - 3 or 7 days after disruption

\subsection{Contamination with toxic substance}

The second scenario deals with the contamination of smaller scale source B (15\%) on Fig. 4; i.e. surface source. If target of contamination it is not only source itself, but whole network, the contamination could be done almost everywhere (secondary sources, main pipelines). Quantity level of toxic substance to water volume determines the consequences in scenario. We presume the hazardous substance with very high toxicity, where small concentration can lead to high consequences. The impacts of contamination by toxic substance are in Table 2.

\begin{tabular}{|c|c|}
\hline Public assets & Impacts \\
\hline $\begin{array}{l}\text { Lives and health of } \\
\text { humans }\end{array}$ & $\begin{array}{l}0 \text { h: the first humans drinking the contaminated water, which started bad processes in the human } \\
\text { body. } \\
12 \text { h: heavy damage to the health which is dependent on the character of used chemical, the first } \\
\text { casualties. } \\
24 \text { h: number of casualties reaching a disastrous amount. The social tension starts. } \\
3 \text { days: stress and worsening of mental status of the survive humans in the affected area, and } \\
\text { also in the extensive vicinity of affected area. Distrust in the central source of drinking water, } \\
\text { which may cause panic and social unrest. Dehydration causing headaches and lower blood } \\
\text { pressure. } \\
7 \text { days: at all the population it is seen the stress from emergency situations and it is also worsened } \\
\text { its mental state. The deteriorating level of hygiene. Dehydration is already causing serious health } \\
\text { complications. }\end{array}$ \\
\hline Human security & $\begin{array}{l}0 \text { h: poisoning by contaminated water in the vicinity. } \\
12 \mathrm{~h} \text { : poisoning by contaminated water from network in the whole area. } \\
24 \mathrm{~h} \text { : the increase in tension in the society. } \\
3 \text { days: } \\
7 \text { days: a decline in the quality of emergency services may lead to the origin of other disasters. }\end{array}$ \\
\hline
\end{tabular}




\begin{tabular}{|c|c|}
\hline Property & $\begin{array}{l}0 \mathrm{~h} \text { : contamination of property, the function of which is associated with the supply of water in } \\
\text { the vicinity, e.g. household equipment, workplaces equipment, machines. } \\
12 \mathrm{~h} \text { : contamination of property, the function of which is associated with the supply of water in } \\
\text { the area, e.g. stocked household equipment, workplaces equipment, and machines. } \\
24 \mathrm{~h} \text { : } \\
3 \text { days: the lack of water for fire-fighting as a consequence of disconnecting the water supply. } \\
7 \text { days: the danger of unrest within the human society which leads to the looting and destruction } \\
\text { of property. Property damage caused by fire, the occurrence likelihood of which increases due } \\
\text { to the degradation of society. }\end{array}$ \\
\hline $\begin{array}{l}\text { Public } \\
\text { (welfa1 }\end{array}$ & $\begin{array}{l}0 \mathrm{~h} \text { : } \\
12 \mathrm{~h} \text { : interruption of work activities in the private and the public sphere as the consequence of } \\
\text { human deaths. } \\
24 \mathrm{~h} \text { : worsening the situation in the human society, the panic induced by the number of victims. } \\
\text { Negative effect on the perception of territory in the future. } \\
3 \text { days ago: } \\
7 \text { days: to fears of poisoning the dangerous substance it adds the fear from a long-term } \\
\text { interruption of drinking water supply. }\end{array}$ \\
\hline Envi & $\begin{array}{l}0 \text { h: contamination of water in the Klíčava water reservoir, the lower reaches of Klíčava stream, } \\
\text { the Berounka River. } \\
12 \mathrm{~h} \text { : the contamination of further water streams (in the river basin of Vltava River and Elbe } \\
\text { River), contamination of rivers banks. The death of aquatic fauna and possible necrosis of flora. } \\
24 \text { h: death of animals that use surface water sources in the affected area. } \\
3 \text { days: } 7 \text { days: }\end{array}$ \\
\hline $\begin{array}{l}\mathrm{Wa} \\
\text { syst }\end{array}$ & $\begin{array}{l}0 \text { h: contamination of drinking water source in the Klíčava water reservoir, contamination of } \\
\text { adjacent network for drinking water supply. } \\
12 \mathrm{~h} \text { : contamination of entire circuit of network for drinking water supply. } \\
24 \text { h: shut down of affected system of drinking water supply. } \\
3 \text { days ago: } \\
7 \text { days: degradation of mechanical parts of system of drinking water supply (the elements of } \\
\text { the system are not in a status for which they have been designed). }\end{array}$ \\
\hline $\begin{array}{l}\text { Emergency } \\
\text { services (police, } \\
\text { fire-fighters, } \\
\text { paramedics) }\end{array}$ & $\begin{array}{l}0 \mathrm{~h}: \\
12 \mathrm{~h} \text { : the extreme load of health care by humans with symptoms of poisoning, and dying, e.g., } \\
\text { hospitals, paramedics and medical rescue service. Increasing demands on the maintenance of } \\
\text { public order. Affecting the human resources from the emergency services. } \\
24 \mathrm{~h} \text { : outage of some sources of water for fire fighting. } \\
3 \text { days ago: } \\
7 \text { days: the decline of physical capabilities of emergency services workers caused by } \\
\text { dehydration. }\end{array}$ \\
\hline Transpor & $\begin{array}{l}0 \mathrm{~h}: 12 \mathrm{~h} \text { : } \\
24 \mathrm{~h} \text { : huge panic is caused by the formation of traffic jams that originated on roads as a result } \\
\text { of mass evacuation of population from affected area. The outage of internal elements of } \\
\text { territorial railway network. Disruption of linear elements of transport infrastructure as result of } \\
\text { social unrest. } \\
3 \text { days, } 7 \text { days }\end{array}$ \\
\hline $\begin{array}{l}\text { Other basic } \\
\text { services and } \\
\text { critical } \\
\text { infrastructures } \\
\text { (informational, } \\
\text { financial, energy, } \\
\text { social, State) }\end{array}$ & $\begin{array}{l}0 \mathrm{~h}: \\
12 \mathrm{~h} \text { : non-availability of basic services, e.g. educational institutions, governmental (public } \\
\text { administration) and financial services. } \\
24 \mathrm{~h} \text { : loss of packaged liquids in stores and distribution centres. } \\
3 \text { days ago: } \\
7 \text { days: malfunction of internal elements of basic infrastructures and critical services. }\end{array}$ \\
\hline
\end{tabular}

Table 2. The impacts of contamination by toxic substance; $0 \mathrm{~h}$ - time of contamination occurrence; $12 \mathrm{~h}$ - after $12 \mathrm{~h}$ of contamination origin, $24 \mathrm{~h}$ - after $24 \mathrm{~h}$ of contamination origin, 3 days and 7 days - after 3 or 7 days of contamination origin

The drinking water supply failure is one of possible critical disasters on the territory of the Czech Republic. Duty of ensuring the drinking water supply even in emergency situations is holding from the 80s of last century according to the law No. 274/2001 Sb., on water supplies and sewerages also in emergency situations, but it cannot be in the long term. The failure of critical infrastructure, where the drinking water supply failure has a high criticality, threatens always a number of other protected assets. 
Possibilities, leading to drinking water supply failure are a number, and they have various relevant impacts and have also different occurrence probabilities. The article presents the impacts for two different causes. Sources of drinking water are the key components of infrastructure, but further critical points can occur, when network topology is wrong or week.

The first scenario deals with the pipeline accident, which ensures the water distribution. The pipeline cracks are relatively common phenomena, which can be caused by various causes. The second scenario deals with the contamination of water source. The contamination of water source is one of terrorist attacks scenarios. But, the contamination may also occur in other ways, accident during the transport of dangerous substances, or bad management of hazardous substances, e.g. during the storage. Both phenomena have already occurred in the Czech Republic, fortunately without critical consequences.

When the impacts of both scenarios are compared, we see the differences mainly in the first hours, where the impacts of contamination are faster. The impacts of both scenarios become similar after exceeding one day. The prevention of serious impacts in the first hours of contamination requires the high-quality monitoring (fish, physical parameters). Monitoring needs to be implemented in all critical sites, not only to the resources. The situation sharply changes after crossing one day in the case of both scenarios. The defeat of emergency situation in 24 hours is associated with relatively small impacts on the protected interests. Exceeding one day, however, leads to a critical situation. The next limit 5-7 days is then given by particular time during which the healthy human is able to endure without water [15].

\section{Future research plans}

The further research is planned to focus in particular on the response to all life sustaining infrastructure failures, to which indisputably the infrastructure ensuring the drinking water supply belongs. The main proposal is to improve the capability to respond to current and future challenges in the drinking water infrastructure. Furthermore to propose activities to identify failure or possible disasters that may induce a critical situation.

\section{Conclusion}

The research was directed to identification of impacts of drinking water supply failure. We have identified two basic problems in managing the situation on the basis of carried out research. The first one is the issue of responsibilities [11]. Many top public administration workers do not know or does not admit all types of responsibilities associated with their position in public administration. This may lead to a delay in the response itself, which it is fatal especially in the case of contamination. The second problem is the robustness of response to the drinking water supply failure. As mentioned above, the drinking water infrastructure failure is identified as one of the possible disasters that may induce a critical situation, and therefore, it is processed contingency (type response) plan for it [1]

On the analysis of actual drinking water supply failures in the Czech Republic in recent years [11], some of response activities, e.g. informing the population, warning the population, emergency supply, rapid restoration of network, are not robust enough. Many of territorial units (communities) are able to solve the demands only in the case of small accidents of water series. Real response plans for the critical failures, however, have not been set up yet. The concept of "smart cities" needs to take account the facts given above and it needs to include the plans for a high-quality and quick response to all life sustaining infrastructure failures, to which indisputably the infrastructure ensuring the drinking water supply belongs.

\section{Acknowledgement}

Authors thanks to the Czech Technical University in Prague for support (grant SGS2015-17) and project SSZP $4771675 / 2019$.

\section{References}

[1] Procházková, D. (2013). Crisis management for Technical Fields. ISBN 978-80-01-05292-1. Praha: ČVUT , 303p.

[2] Procházková, D. (2012). Critical Infrastructure Safety. Praha: ČVUT, ISBN 978-80-01-05103-0, 318p.

[3] Procházková, D. (2013). Principals of Critical Infrastructure Safety Management. ISBN 978-80-01-05245-7. Praha: ČVUT, 223p.

[4] EU.ESRIF Final Report. Brussels: EU 2009, 319p.

[5] US.US Critical Infrastructure Conception. Washington: US Government 2001.

[6] EMA.Critical Infrastructure Emergency Risk Management and Assurance. Handbook Emergency Management Australia, 2003, www.ema.gov.au

[7] Domains of Critical Infrastructure in the Czech Republic. Usn. vlády ČR č. 1436 ze dne 19. prosince 2007 (usnesení BRS ze dne 3. července 2007 č. 30)

[8] Procházková, D. (2011). Analysis and Management of Risks. ISBN 978-80-01-04841-2, Praha: ČVUT Praha.

[9] Patáková, H. \& Procházka, J. (2013). Analysis of Data on Traffic Incidents with Presence of Hazardous Substances. Proceedings of the 11th European Transport Congress, ISBN 978-80-01-05321-8. 
[10] Patáková, H. (2014). Critical Sites at Transportation of Hazardous Substances on Highway D1. Diploma Thesis. Praha: ČVUT, 124p.

[11] Vašatová, L. (2016). Risks Connected with Failure of Drinking Water. Diploma Thesis. Praha: ČVUT, 74p.

[12] ASCE. Global Blueprints for Change - Summaries of the Recommendations for Theme A „Living with the Potential for Natural and Environmental Disasters“, Summaries of the Recommendations for Theme B „Building to Withstand the Disaster Agents of Natural and Environmental Hazards“, Summaries of the Recommendations for Theme C „Learning from and Sharing the Knowledge Gained from Natural and Environmental Disasters“. ASCE, Washington 2001.

[13] Tomek, M. \& Seidl, M. (2007). Emergency Supply of Public by Drinking Water. In: Ochrana obyvatelstva. ISBN 80-86634-51-5. Ostrava: SPBI, pp.372-378.

[14] Monoši, M. \& Orinčák, M. (2007). Risks of Threat of Waterworks Reservoirs on the Slovak Republic Territory. In: Ochrana obyvatelstva, ISBN 80-86634-51-5. Ostrava: SPBI, pp. 218-224.

[15] VÚV. Technical Documentation of Ducts and Sewerage. Praha: Vodovody a kanalizace a.s.

[16] KÚ Středočeského kraje. Database of Water Network in Central Bohemia. Praha: Středočeský krajský úřad.

[17] Kralikova, R.; Sokolova, H. ; Wessely, E. \& Polak, J. (2013). Approaches to assessment of hot environment. DAAAM International Scientific Book 2013. chapter 14. Vienna. DAAAM International. p. 317-328. ISBN 9783-901509-94-0

[18] Procházková, D.; Wessely, E.; Rusko, M. \& Kralikova, R. (2011). Human System Safety Management and Environmental Management Relation. In DAAAM International Scientific Book 2011. s.103-118. ISSN 1726-9687; DOI: $10.2507 /$ daaam.scibook.2011.09 